\title{
Purification of Four Penicillin-binding Proteins from Bacillus megaterium
}

\author{
By HOWARD A. CHASE \\ Sub-Department of Chemical Microbiology, Department of Biochemistry, \\ University of Cambridge, Tennis Court Road, Cambridge CB2 $1 Q W$
}

(Received 17 July 1979)

\begin{abstract}
Four of the five penicillin-binding proteins in the cytoplasmic membranes of Bacillus megaterium have been purified to protein homogeneity. The method used involved the solubilization of the penicillin-binding proteins from the membranes by treatment with non-ionic detergent, followed by partial separation of the proteins by ion-exchange chromatography on DEAE-Sepharose CL-6B. Each protein was then purified to protein homogeneity by covalent affinity chromatography on ampicillin-affinose. The protein with the lowest molecular weight is a DD-carboxypeptidase. The other three proteins have previously been postulated to be peptidoglycan transpeptidases, endopeptidases or DD-carboxypeptidases in vivo, but it was not possible to demonstrate any of these activities with the purified proteins in various in vitro systems. Possible reasons for the observed lack of enzymic activity in vitro are discussed.
\end{abstract}

\section{INTRODUCTION}

The most generally accepted hypothesis for the lethal action of $\beta$-lactam antibiotics on bacterial cells is that they inhibit enzymes that catalyse the terminal stages of peptidoglycan synthesis (Blumberg \& Strominger, 1974). These penicillin-sensitive enzymes have been postulated to be peptidoglycan transpeptidases, endopeptidases and D-alanyl-D-alanine carboxypeptidases (DD-carboxypeptidases, EC 3.4.12.6; these catalyse the hydrolysis of the terminal D-alanine residue from peptide substrates with a C-terminal sequence of D-alanyl-D-alanine). The initial inhibitory action of $\beta$-lactam antibiotics may then be followed by an increase in autolytic activity in the cells which results in lysis and death (Tomasz \& Höltje, 1977). Hence, an understanding of the molecular mechanism of penicillin action requires knowledge of the interaction of penicillins with the penicillin-sensitive enzymes and of how this interaction leads to the death of the cell. However, the identification, purification and characterization of the proteins that act as receptors for the lethal action of $\beta$-lactams has proved elusive for a number of years.

The cytoplasmic membranes of bacteria contain a number of proteins that bind ${ }^{14} \mathrm{C}$ labelled benzylpenicillin covalently (penicillin-binding proteins; PBPs) and it is assumed that at least one of these proteins is the enzyme whose inhibition by $\beta$-lactam antibiotics leads eventually to the death of the cell (Blumberg \& Strominger, 1974). Two complementary approaches have been used to elucidate the functions of the penicillin-binding proteins. The principle behind the genetic approach is to isolate mutants lacking one or more of the penicillin-binding proteins and then to discover what effect these mutations have on the growth or morphology of the cell; this is followed by an investigation of the loss of any biochemical activities in the mutants. This approach has allowed functions to be assigned to some of the penicillin-binding proteins of Escherichia coli (Spratt, 1975; Spratt, 1977; 
Iwaya \& Strominger, 1977; Tamaki et al., 1977) but has not been used for any other microorganism. The second, biochemical, approach to determine the functions of the penicillinbinding proteins involves their purification followed by an investigation of their enzymic activities. This is the approach used in the work described in this report. In all the organisms examined to date, the penicillin-binding protein with the lowest molecular weight has been found to possess DD-carboxypeptidase activity. Thus in Bacillus subtilis, PBP5 is a DDcarboxypeptidase (Blumberg \& Strominger, 1972), as is PBP5/6 of E. coli (Spratt \& Strominger, 1976), PBP5 of Salmonella typhimurium (Shepherd et al., 1977) and PBP3 of Bacillus stearothermophilus (Yocum et al., 1974). However, comparable studies have not been carried out with the penicillin-binding proteins of higher molecular weight from any organism although these proteins are more likely to be closely involved with the lethal effects of $\beta$-lactams than are the DD-carboxypeptidases.

Covalent affinity chromatography has enabled the purification of the DD-carboxypeptidases in high yield in a single-step process. In this technique, first described by Blumberg \& Strominger (1972), the penicillin-binding proteins are bound covalently to a derivative of penicillin attached to an inert support and are separated from other proteins which do not bind to the affinity resin. The penicillin-binding proteins are removed from the affinity resin by treatment with hydroxylamine, a reagent that has been shown to break the covalent bond between penicillin and the DD-carboxypeptidases (Lawrence \& Strominger, 1970).

One of the major problems in the study of the lethal action of penicillin has been the development of a suitable in vitro system for assaying the complex peptidoglycan transpeptidation reactions. The natural model transpeptidation reaction, in which two molecules of the pentapeptide substrate L-alanyl- $\gamma$-D-glutamyl-meso-2,6-diaminopimelyl-D-alanyl-Dalanine [L-Ala-D-Glu-( $m s-\mathrm{A}_{2}$ pm-D-Ala-D-Ala)] acting both as donor and acceptor are linked by transpeptidation to form a nonapeptide, is assumed to be a good model of the presumed in vivo transpeptidation reaction in organisms that have a cell wall structure that is crosslinked by a bond formed between a D-alanine residue of one side-chain and the D centre of a meso-diaminopimelyl residue in another (Nguyen-Distèche et al., 1974). This model reaction is catalysed by PBPs 4 and 5 of S. typhimurium (Shepherd et al., 1977), material solubilized from the membranes of $E$. coli (Nguyen-Distèche et al., 1974) and the purified DD-carboxypeptidase of the L-form of Proteus mirabilis (Martin et al., 1976). The structure of the cell wall of Bacillus megaterium is such that a similar transpeptidation reaction in vivo would be expected.

The cytoplasmic membranes of B. megaterium contain five penicillin-binding proteins which have been numbered 1 to 5 in order of decreasing molecular weight (Chase et al., 1977). The characteristics of the interaction of benzylpenicillin with PBP1 are consistent with this protein being a peptidoglycan transpeptidase whose inhibition by benzylpenicillin results in death of the cell (Reynolds et al., 1978). It is possible to demonstrate peptidoglycan transpeptidase activity catalysed by cell wall plus membrane fragments of $B$. megaterium (Reynolds, 1971) and in an attempt to demonstrate that this activity is catalysed by PBP1, this protein has been solubilized from the membranes and purified to protein homogeneity (Chase et al., 1978). Some preliminary work on the enzymic activities of PBPs 1,3 and 4 , when studied in partially purified preparations (Chase et al., 1977), suggested that these proteins are devoid of DD-carboxypeptidase and transpeptidase activities. PBP5 has also been purified to protein homogeneity (Chase et al., 1977) and has been shown to be a DD-carboxypeptidase but the characteristics of the binding of benzylpenicillin to this protein exclude it from consideration as the lethal target for $\beta$-lactams.

The aim of the work described here was to purify as many as possible of the penicillinbinding proteins of $B$. megaterium and to determine their enzymic activities. 


\section{METHODS}

Bacterial strain and growth conditions. Bacillus megaterium strain KM was used throughout this study. The growth medium contained (per litre) $10 \mathrm{~g}$ tryptone (Difco Bacto), $5 \mathrm{~g}$ yeast extract (Difco Bacto), $2 \cdot 5 \mathrm{~g}$ $\mathrm{K}_{2} \mathrm{HPO}_{4}$ and $1 \mathrm{~g}$ glucose; the $\mathrm{pH}$ was adjusted to $7 \cdot 2$. The organisms were cultured in 21 Erlenmeyer flasks containing $800 \mathrm{ml}$ growth medium in a Gallenkamp orbital incubator $\left(200 \mathrm{rev} . \mathrm{min}^{-1}\right)$ at $37^{\circ} \mathrm{C}$. Growth was followed turbidimetrically using a Hilger 'Spekker' absorptiometer with neutral filters.

Preparation of membranes. Batches of cells were harvested in the exponential phase of growth at a culture density of $0.4 \mathrm{mg}$ dry $\mathrm{wt} \mathrm{m}^{-1}$ by centrifuging at $8500 \mathrm{rev} . \mathrm{min}^{-1}(12000 \mathrm{~g}$ approx.) for $2 \mathrm{~min}$ in a Sorvall RC-5 centrifuge (GS-3 rotor). Lysed protoplast membranes were prepared by treatment of cells with lysozyme (EC 3.2.1.17; Sigma) and the membranes were obtained as described by Chase et al. (1978); they were stored at a density of $10 \mathrm{mg}$ protein $\mathrm{ml}^{-1}$ in $50 \mathrm{~mm}$-Tris/ $\mathrm{HCl}$ buffer, $\mathrm{pH} 7 \cdot 2$ at $-25^{\circ} \mathrm{C}$.

Solubilization of membrane-bound penicillin-binding proteins. Membranes were sedimented by centifuging at $50000 \mathrm{~g}$ for $20 \mathrm{~min}$ and resuspended at a density of $10 \mathrm{mg}$ protein $\mathrm{ml}^{-1}$ in $50 \mathrm{~mm}$-Tris $/ \mathrm{HCl}$ buffer, $\mathrm{pH} 8.0$ containing various amounts of the non-ionic detergent isotridecanol polyglycol ether (trivial name: Genapol $\mathrm{X}-100$; the kind gift of Farbwerke Hoeschst, Frankfurt, Germany) and NaCl. Solubilization was achieved by incubation at $37^{\circ} \mathrm{C}$ for $10 \mathrm{~min}$ with constant stirring. Insoluble material was removed by centrifuging at $4{ }^{\circ} \mathrm{C}(165000 \mathrm{~g}, 1 \mathrm{~h})$.

Ion-exchange chromatography. Membranes $(20 \mathrm{ml}, 200 \mathrm{mg}$ protein) from $B$. megaterium were solubilized with $1 \mathrm{M}-\mathrm{NaCl} / 1 \%(\mathrm{w} / \mathrm{v})$ Genapol X-100/50 mm-Tris/HCl buffer, $\mathrm{pH} 8 \cdot 0$, as described above. The solubilized material was dialysed against $5150 \mathrm{~mm}$-2-amino-2-methylpropane-1,3-diol/ $\mathrm{HCl}$ buffer, $\mathrm{pH} 9 \cdot 5$, containing $0.1 \%(\mathrm{w} / \mathrm{v})$ Genapol X-100 and applied to a $200 \mathrm{ml}$ column of DEAE-Sepharose CL-6B (Pharmacia) equilibrated in similar buffer. The column was eluted at $4{ }^{\circ} \mathrm{C}$ with a linear gradient of $\mathrm{NaCl}(0$ to $0.5 \mathrm{M})$ in 21 of the above buffer at a flow rate of $80 \mathrm{ml} \mathrm{h}^{-1}$ and $20 \mathrm{ml}$ fractions were collected.

Covalent affinity chromatography. Covalent affinity chromatography was performed using ampicillinaffinose prepared from Affi-Gel 202 (Bio-Rad) to which ampicillin had been coupled by the method described by Pollock et al. (1974). For all experiments, a $4 \mathrm{~cm} \times 1 \mathrm{~cm}$ column of ampicillin-affinose was used and the affinity resin was equilibrated against $10 \mathrm{~mm}$-sodium cacodylate $/ \mathrm{HCl}$ buffer, $\mathrm{pH} 6.0$ containing $0 \cdot 1 \%$ (w/v) Genapol X-100. The material to be chromatographed was incubated with the ampicillin-affinose for $10 \mathrm{~min}$ at $37^{\circ} \mathrm{C}$ in order that the penicillin-binding proteins should bind to the resin, after which the column was poured. Proteins that did not bind covalently to the resin were removed by washing at $4{ }^{\circ} \mathrm{C}$ with $50 \mathrm{ml} 1 \mathrm{M}-\mathrm{NaCl}$ in $50 \mathrm{~mm}$-Tris $/ \mathrm{HCl}$ buffer, $\mathrm{pH} 8.8$ containing $0.1 \%\left(\mathrm{w} / \mathrm{v}\right.$ ) Genapol X-100 (flow-rate $150 \mathrm{ml} \mathrm{h}^{-1}$ ). Proteins that were bound covalently to the column were eluted by incubation of the affinity resin with successive $2 \mathrm{ml}$ portions of neutralized $1 \mathrm{M}$-hydroxylamine hydrochloride in $0.5 \mathrm{M}$-Tris $/ \mathrm{HCl}$ buffer, $\mathrm{pH} 8.8$ containing $0.1 \%(\mathrm{v} / \mathrm{v})$ Genapol X-100. Hydroxylamine was removed by dialysis at $4{ }^{\circ} \mathrm{C}$ against two 51 quantities of $25 \mathrm{~mm}$-Tris/ $\mathrm{HCl}$ buffer, $\mathrm{pH} 8 \cdot 0$.

Assay of penicillin-binding proteins by sodium dodecyl sulphate-polyacrylamide gel electrophoresis. The presence of penicillin-binding proteins was assayed by treatment of a sample with $\left[{ }^{14} \mathrm{C}\right]$ benzylpenicillin followed by preparation of the sample for sodium dodecyl sulphate (SDS)-polyacrylamide gel electrophoresis. Samples were incubated with $\left[{ }^{14} \mathrm{C}\right]$ benzylpenicillin [potassium 6-phenyl[1-14 C]acetamidopenicillanate, $15 \mu \mathrm{g}$ $\mathrm{ml}^{-1}$; sp.act. $52 \mathrm{Ci} \mathrm{mol}^{-1}\left(1.92 \mathrm{TBq} \mathrm{mol}^{-1}\right)$; The Radiochemical Centre, Amersham] for $10 \mathrm{~min}$ at $37^{\circ} \mathrm{C}$ followed by addition of unlabelled benzylpenicillin $\left(10 \mathrm{mg} \mathrm{ml}^{-1}\right)$ and $4 \mathrm{vol}$. acetone to precipitate the protein. The samples were stored at $-30^{\circ} \mathrm{C}$ for $20 \mathrm{~min}$ and the precipitate was collected by centrifuging at $10000 \mathrm{~g}$ for $20 \mathrm{~min}$, dried in vacuo, and redissolved by boiling for $2 \mathrm{~min}$ in $10 \mathrm{~mm}$-Tris/ $\mathrm{HCl}$ buffer, $\mathrm{pH} 7 \cdot 2$ containing $10 \%(\mathrm{w} / \mathrm{v})$ glycerol, $1 \%(\mathrm{w} / \mathrm{v})$ SDS, $1 \%(\mathrm{v} / \mathrm{v}) 2$-mercaptoethanol and $0.002 \%(\mathrm{w} / \mathrm{v})$ bromophenol blue. Discontinuous electrophoresis in polyacrylamide slab gels containing SDS was carried out essentially as described by Laemmli \& Favre (1973), but at a constant voltage of $100 \mathrm{~V}$ until the samples had penetrated the stacking gel, and thereafter at a constant voltage of $450 \mathrm{~V}$ with cooling of the apparatus. The composition of the running gel $(15 \mathrm{~cm} \times 15 \mathrm{~cm} \times 2 \mathrm{~mm})$ was $10 \%(\mathrm{w} / \mathrm{v})$ acrylamide and $0.13 \%(\mathrm{w} / \mathrm{v})$ methylene bisacrylamide. The running gel was topped by a $1 \mathrm{~cm}$ layer of stacking gel. Gels were stained with Coomassie brilliant blue according to the method of Fairbanks et al. (1971) and destained in $10 \%(\mathrm{v} / \mathrm{v})$ acetic acid. In order to detect the radioactive bands, the gels were prepared for fluorography by impregnation with the scintillant 2,5-diphenyloxazole as described by Bonner \& Laskey (1974) and Laskey \& Mills (1975). In order to relate accurately the image densities obtained on the X-ray film to the amount of radioactivity in the gel, the X-ray film was sensitized by controlled partial pre-fogging (Laskey \& Mills, 1975). The exposure time for fluorography was $14 \mathrm{~d}$.

Enzymic activities of the isolated proteins. The purified penicillin-binding proteins were assayed for transpeptidase, carboxypeptidase and endopeptidase activities (see Table 1 for details) by incubating $20 \mu \mathrm{l}$ samples with $5 \mu \mathrm{l}$ of the relevant substrate. For some incubations $2 \mu 1150 \mathrm{mM}-\mathrm{MgCl}_{2}$ (final concentration $10 \mathrm{~mm}$ ) 


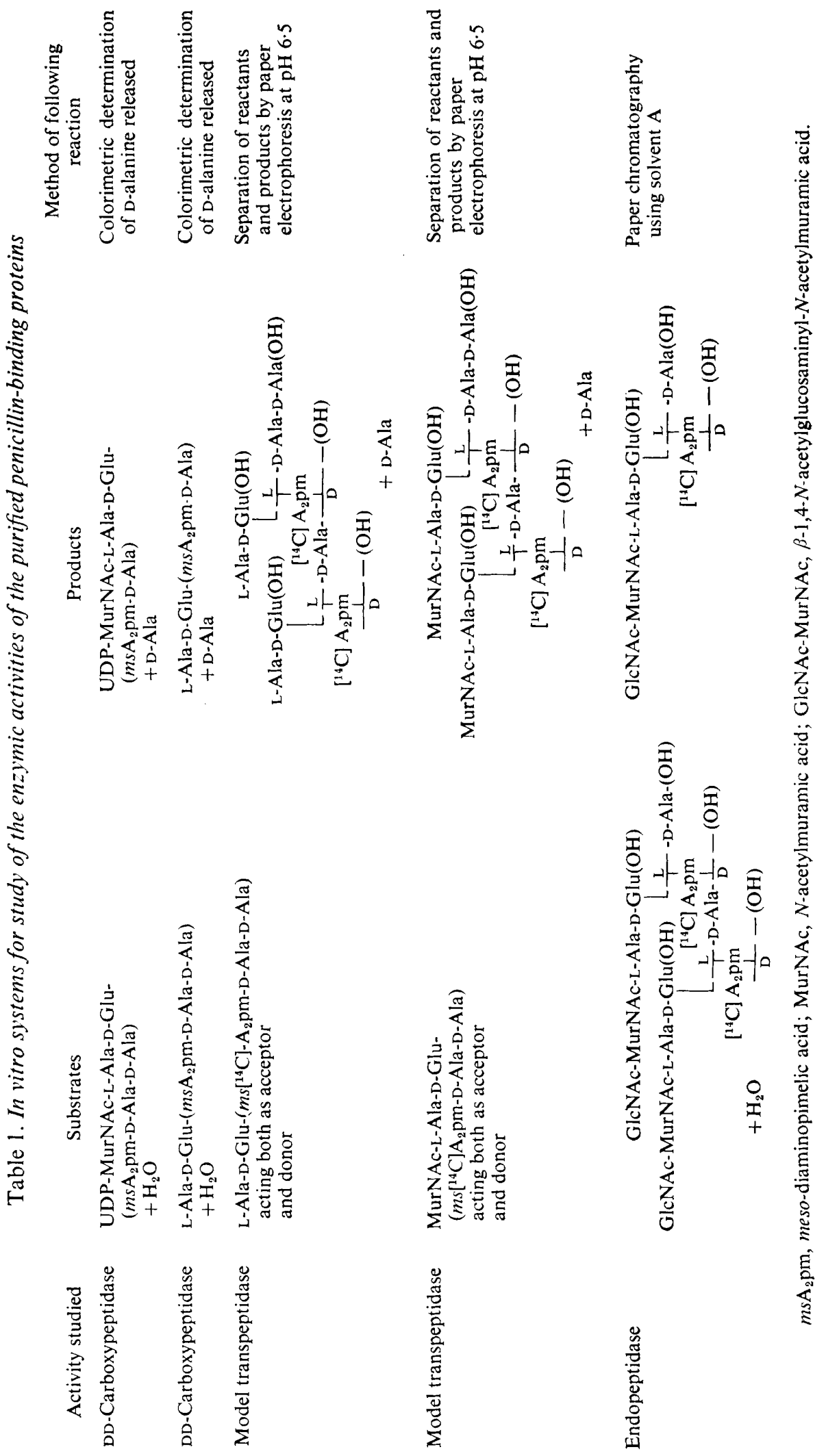


was added, and in order to study the effect of alteration of the pH of the incubation, in some experiments $2 \mu \mathrm{l} 1 \mathrm{M}$-sodium acetate buffer, $\mathrm{pH} 6.0$ or $2 \mu \mathrm{l} 1 \mathrm{M}$-Tris/ $\mathrm{HCl}$ buffer, $\mathrm{pH} 9.0$ was added. All incubations were in a final volume of $30 \mu \mathrm{l}$. The samples were incubated for at least $3 \mathrm{~h}$ at $37^{\circ} \mathrm{C}$ and the reactions were terminated by immersing the tubes in boiling water for $1 \mathrm{~min}$. The extent of the reaction was determined by the methods indicated in Table 1 . When using the substrates that were not radioactively labelled, the reactions were followed by measuring the release of $\mathrm{D}$-alanine. The reactions involving radioactively labelled substrates were followed by separating the reactants from the radioactive products by paper electrophoresis or paper chromatography. The location of radioactivity on the paper was determined by autoradiography, the radioactive areas were cut out and the amount of radioactivity present was determined by liquid scintillation counting using $0.4 \%(\mathrm{w} / \mathrm{v})$ 2,5-bis[2-(5-tert-butylbenzoxazolyl)]thiophene in toluene as scintillant.

Preparation of substrates. UDP- $N$-acetylmuramoyl-L-alanyl- $\gamma$-D-glutamyl-meso-2,6-diaminopimelyl-Dalanyl-D-alanine [UDP-MurNAc-L-Ala-D-Glu-( $m s-\mathrm{A}_{2}$ pm-D-Ala-D-Ala)] was prepared as described by Barnett (1973). L-Ala-D-Glu-(ms $\mathrm{A}_{2}$ pm-D-Ala-D-Ala) was prepared as described by Martin et al. (1976) but with the modifications described by Chase et al. (1978). L-Ala-D-Glu- $\left(m s\left[1,7-{ }^{14} \mathrm{C}\right] \mathrm{A}_{2} \mathrm{pm}-\mathrm{D}-\mathrm{Ala}-\mathrm{D}-\mathrm{Ala}\right)$ was prepared as described by Shepherd et al. (1977).

$\left[{ }^{14} \mathrm{C}\right] \mathrm{Bisdisaccharide} \mathrm{peptide} \mathrm{dimer} \mathrm{(see} \mathrm{Table} 1$ for structure) was prepared from the isolated peptidoglycan of a strain of Escherichia coli that requires diaminopimelic acid for growth. Escherichia coli W7 (Braun et al., 1974) was grown overnight at $37^{\circ} \mathrm{C}$ with vigorous shaking in the medium used for the growth of $B$. megaterium supplemented with diaminopimelic acid $\left(6 \mu \mathrm{g} \mathrm{ml}^{-1}\right)$. In the morning, 31 of similar medium was inoculated

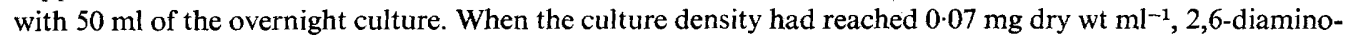
$1,7-{ }^{14} \mathrm{C}$ ]pimelic acid [50 $\mu \mathrm{Ci}$; sp.act. $44 \mathrm{Ci} \mathrm{mol}^{-1}\left(1 \cdot 6 \mathrm{TBq} \mathrm{mol}^{-1}\right)$; The Radiochemical Centre, Amersham] was added and the cells were harvested when a culture density of $0.9 \mathrm{mg}$ dry wt $\mathrm{ml}^{-1}$ had been reached. The cell pellet was washed once in distilled water and resuspended in $50 \mathrm{ml}$ water. Cell disintegration was achieved by sonication; a Dawe 'Soniprobe' type 7532A fitted with a Branson Convertor was used with the output control set to position 5 . The cell suspension was kept at $4{ }^{\circ} \mathrm{C}$ and $30 \mathrm{~s}$ bursts of sonication were used. A total of $4 \mathrm{~min}$ sonication resulted in breakage of more than $90 \%$ of the cells. EDTA $(0 \cdot 1 \mathrm{M}, \mathrm{pH} 7 \cdot 4)$ was added to a final concentration of $0.01 \mathrm{M}$ and the cell envelope preparation was washed three times with water by centrifuging $(50000 \mathrm{~g}, 20 \mathrm{~min})$ and finally resuspended in $8 \mathrm{ml}$ water. Peptidoglycan with attached lipoprotein was isolated from the cell envelope preparation by a procedure modified from that described by Braun \& Rehn (1969). The envelope preparation was added dropwise to $50 \mathrm{ml}$ boiling $4 \%$ (w/v) SDS with constant stirring and was then boiled for a further $10 \mathrm{~min}$. Peptidoglycan/lipoprotein was sedimented by centrifuging at $40000 \mathrm{rev}$. $\mathrm{min}^{-1}$ for $30 \mathrm{~min}$ in the $50 \mathrm{Ti}$ rotor of a Beckman ultracentrifuge ( $105000 \mathrm{~g}$ approx.)

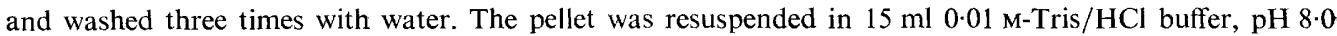
containing $10 \mathrm{~mm}-\mathrm{CaCl}_{2}$. Then $100 \mu \mathrm{g}$ trypsin $(\mathrm{BDH})$ was added and the suspension was shaken vigorously at $37^{\circ} \mathrm{C}$ for $3 \mathrm{~h}$. EDTA was added to a final concentration of $10 \mathrm{~mm}$ followed by $400 \mu \mathrm{g}$ trypsin inhibitor $(\mathrm{BDH})$ and the peptidoglycan was collected by centrifuging $(100000 \mathrm{~g}, 20 \mathrm{~min})$. The peptidoglycan was washed once in water, resuspended in $15 \mathrm{ml} 0.01 \mathrm{M}$-Tris/ $\mathrm{HCl}$ buffer, $\mathrm{pH} 7.2$ and $300 \mathrm{mg}$ lysozyme was added. The preparation was incubated for $24 \mathrm{~h}$ at $37^{\circ} \mathrm{C}$; then a further $100 \mathrm{mg}$ lysozyme was added and incubation was continued for $36 \mathrm{~h}$ at $20^{\circ} \mathrm{C}$. The lysozyme-degraded peptidoglycan was filtered in $0 \cdot 1 \mathrm{M}-\mathrm{LiCl}$ on two columns of Sephadex G-50 and Sephadex G-25 connected in series (Van Heijenoort et al., 1969) which separated disaccharide peptide monomer from bisdisaccharide peptide dimer. Each fraction was desalted by filtration in water on a column of Sephadex G-10 $\left(85 \mathrm{~cm} \times 3 \mathrm{~cm}\right.$; flow rate $\left.80 \mathrm{ml} \mathrm{h}^{-1}\right)$. The volume of the fraction containing bisdisaccharide peptide dimer was reduced to $1.6 \mathrm{ml}$ and the radioactivity was determined to be 3500 d.p.m. $\mu \mathrm{l}^{-1}$.

Paper chromatography. Paper chromatography was carried out on Whatman no. 1 paper for $24 \mathrm{~h}$ at $4{ }^{\circ} \mathrm{C}$ using isobutyric acid/1 M-ammonia $(5: 3, \mathrm{v} / \mathrm{v})$ (solvent A).

Paper electrophoresis. High-voltage paper electrophoresis at $\mathrm{pH} 6.5$ was carried out on Whatman $3 \mathrm{MM}$ paper at $60 \mathrm{~V} \mathrm{~cm}^{-1}$. The buffer used was pyridine/acetic acid/water (100:3:897, by vol.).

Autoradiography. The position of radioactive compounds on chromatograms and electrophoretograms was determined by placing the paper in contact with X-ray film (Kodak Blue Brand) in the dark for 2 weeks, then developing in Ilford Contrast FF developer and fixing in Kodafix fixer.

Estimation of D-alanine. D-Alanine was estimated using a method adapted from that of Johnson et al. 1975 ), with the modifications that water-soluble $o$-dianisidine sulphate was used (allowing methanol to be omitted) and the reactions were terminated by the addition of 4 vol. $0.25 \%(\mathrm{w} / \mathrm{v}) \mathrm{SDS}$.

Estimation of protein. Protein was estimated using the Lowry method with dried bovine serum albumin as standard. Sodium dodecyl sulphate was added to all solutions to a final concentration of $1 \%$ (w/v) in order to prevent the formation of precipitates in the presence of non-ionic detergent.

Ultrafiltration. Ultrafiltration was carried out at $4{ }^{\circ} \mathrm{C}$ in an Amicon model 12 ultrafiltration unit using a UM10 filter. 
Antibiotics. Benzylpenicillin (Crystapen) was purchased from Glaxo Laboratories, Greenford, Middx.; ampicillin (Penbritin) from Beecham Research Laboratories, Brentford, Middx., and cephalothin (Keflin) from Eli Lilly \& Co., Indianapolis, U.S.A.

\section{RESULTS}

\section{Solubilization of the penicillin-binding proteins}

The effect of the concentration of $\mathrm{NaCl}$ in the presence of the non-ionic detergent Genapol $\mathrm{X}-100$ on the solubilization of the penicillin-binding proteins from the cytoplasmic membranes of $B$. megaterium is shown in Fig. 1. The definition of 'soluble' material used in these studies is material that is not sedimented by centrifuging at $165000 \mathrm{~g}$ for $1 \mathrm{~h}$. Similar definitions have been used by other workers (Barnett, 1973), although Penefsky \& Tzagoloff (1971) have pointed out that some procedures may lead to the formation of small membrane fragments that do not sediment readily and may thus appear to be soluble. Treatment of the membranes with $1 \%(\mathrm{w} / \mathrm{v})$ Genapol X-100 in 50 mM-Tris/ $\mathrm{HCl}$ buffer, $\mathrm{pH} 8.0$ for $10 \mathrm{~min}$ at $37^{\circ} \mathrm{C}$ resulted in the solubilization of most of PBPs $1,3,4$ and 5. Complete solubilization of these penicillin-binding proteins was achieved if $\mathrm{NaCl}$ was added to a final concentration of between 0.5 and $2 \mathrm{M}$. The extraction of firmly associated membrane proteins is to some extent dependent on the ratio of detergent to membrane lipid (Helenius \& Simons, 1975) and treatment with $0 \cdot 1 \%(\mathrm{w} / \mathrm{v})$ Genapol X-100 resulted in only poor solubilization of the penicillin-binding proteins. Solubilization with $5 \%(\mathrm{w} / \mathrm{v})$ Genapol X-100 was, however, not significantly better than that using $1 \%$ detergent. On the basis of these results, treatment with $1 \%$ Genapol $\mathrm{X}-100$ and $1 \mathrm{M}-\mathrm{NaCl}$ in $50 \mathrm{~mm}-\mathrm{Tris} / \mathrm{HCl}$ buffer, $\mathrm{pH} 8.0$ for $10 \mathrm{~min}$ at $37^{\circ} \mathrm{C}$ was chosen as the standard condition for the solubilization of PBPs $1,3,4$ and 5 of B. megaterium. PBP2 appeared to be very unstable and lost its penicillin-binding activity under the conditions used for solubilization. After incubation of membranes, even in the absence of detergent, for $10 \mathrm{~min}$ at $37^{\circ} \mathrm{C}$ followed by centrifuging, this penicillin-binding protein could not be detected in either the pellet or the supernatant.

\section{Isolation of the penicillin-binding proteins}

A flow chart of the procedure used to purify the penicillin-binding proteins is given in Table 2. The penicillin-binding proteins were partially separated from each other by ionexchange chromatography of the material solubilized from the membranes on DEAESepharose CL-6B as described previously (Chase et al., 1978) (Fig. 2). PBP5 and PBP3 were eluted in the same fractions but PBP4 was completely separated from the other penicillinbinding proteins in fractions 33 to 35 . As had been observed previously, all fractions that contained PBP1 also contained PBP4.

Penicillin-binding proteins were isolated from the fractions obtained after ion-exchange chromatography by covalent affinity chromatography on ampicillin-affinose. The fractions resulting from ion-exchange chromatography that contained PBP4 as the sole penicillinbinding protein $(33,34$ and 35$)$ were pooled and concentrated by ultrafiltration. PBP4 was then isolated by covalent affinity chromatography on ampicillin-affinose. Examination of the hydroxylamine eluates by SDS-polyacrylamide gel electrophoresis showed that PBP4 had been purified to homogeneity. It could be visualized as a single band after staining with Coomassie brilliant blue (Fig. $3 a$ ) and on the corresponding fluorogram (Fig. $3 b$ ).

Although all fractions that contained PBP1 also contained PBP4, it was possible to isolate PBP1 from fractions 37 to 49 by the procedure described previously by Chase et al. (1978). This technique exploits the observation that the rates of elution by hydroxylamine of PBP1 and PBP4 are substantially different (Chase et al., 1977) and it is thus possible to obtain fractions after covalent affinity chromatography that contain PBP1 but not PBP4.

It has not proved possible to separate PBP3 from PBP5 by ion-exchange chromatography so the technique described above to isolate PBP4 could not be used to isolate PBP3. Also, 


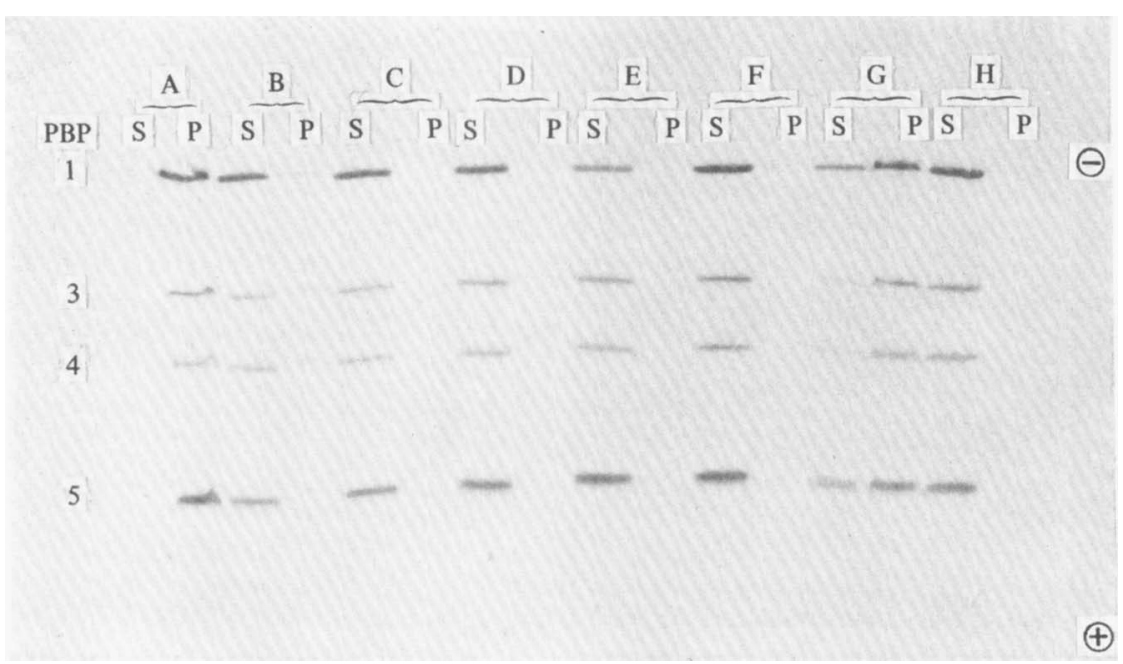

Fig. 1. Solubilization of the membrane-bound penicillin-binding proteins of $B$. megaterium as visualized by fluorography. Samples of the supernatants (S) and the residual pellets (P) after solubilization were analysed by SDS-polyacrylamide gel electrophoresis and the penicillin-binding proteins (PBP) were detected by fluorography. The concentrations of Genapol X-100 $(\%, w / v)$ and $\mathrm{NaCl}$ (M) used in the solubilization experiments were: (A) 0,$0 ;$ (B) 1,$0 ;$ (C) $1,0 \cdot 2 ;$ (D) $1,0 \cdot 5$; (E) 1,$1 ;$ (F) 1,$2 ;(\mathrm{G}) 0 \cdot 1,0 \cdot 5 ;$ (H) $5,0 \cdot 5$. The polarity of electrophoresis is shown on the figure.

Table 2. Purification of the penicillin-binding proteins of B. megaterium: flow chart

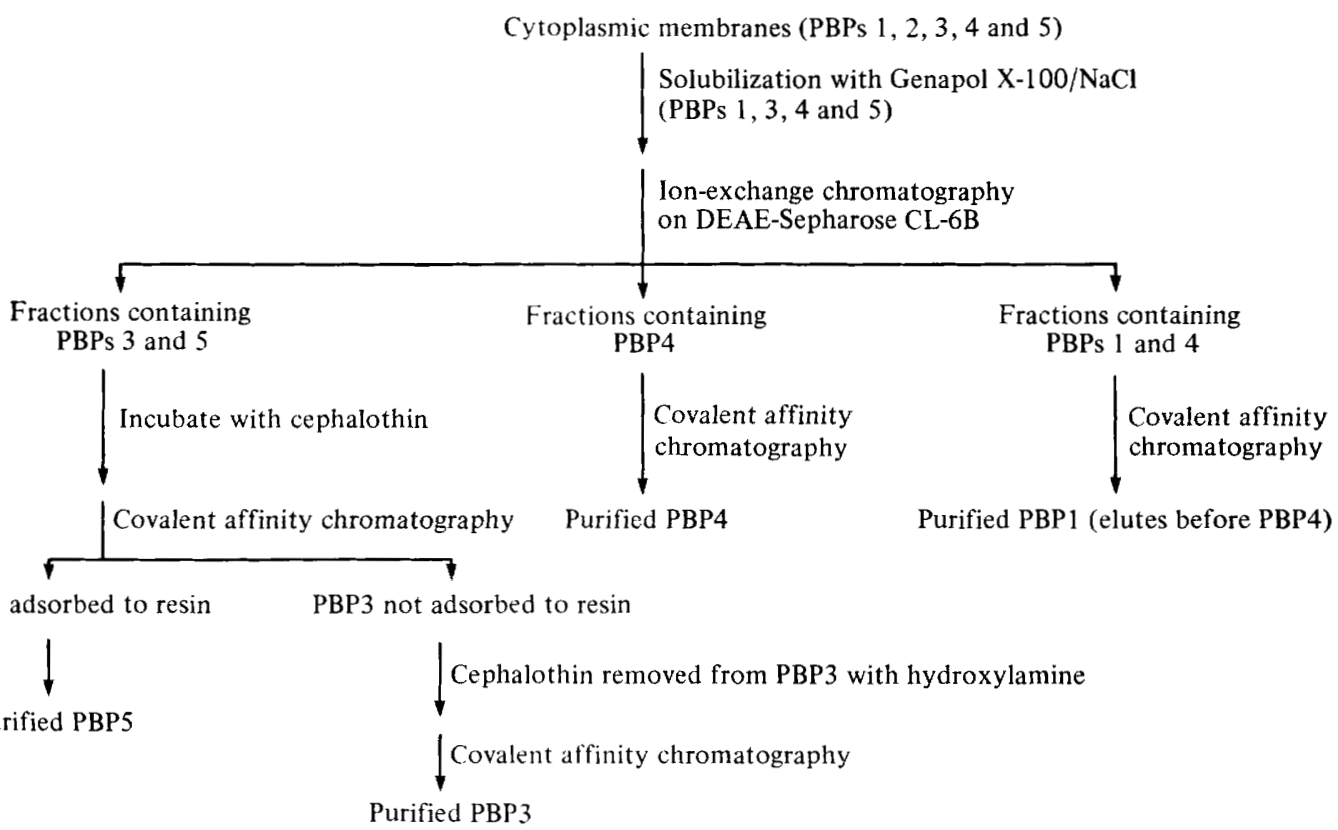




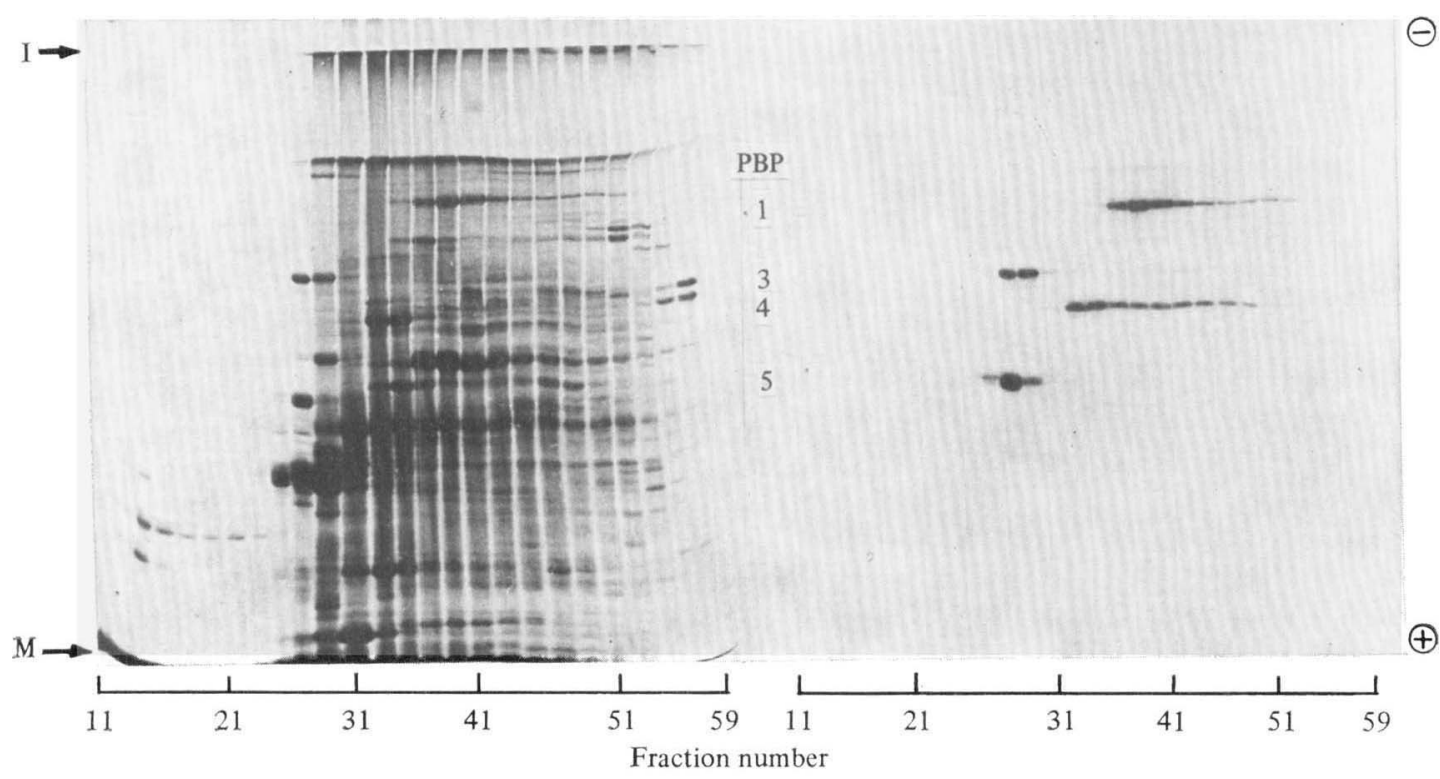

(a)

(b)

Fig. 2. Separation of the penicillin-binding proteins of $B$. megaterium by ion-exchange chromatography. Chromatography on DEAE-Sepharose was carried out as described in the text and in Methods. Samples $(1 \mathrm{ml})$ of alternate fractions were analysed by SDS-polyacrylamide gel electrophoresis. Proteins were revealed by staining with Coomassie brilliant blue $(a)$ and penicillin-binding proteins were revealed by fluorography $(b)$. I indicates the position of the interface between the stacking and the running gels and $\mathbf{M}$ marks the position of the bromophenol blue marker.

although PBP3 is eluted from ampicillin-affinose by hydroxylamine more slowly than PBP5 the rates of elution of these two penicillin-binding proteins are not sufficiently different to be able to separate the two proteins, as was possible with PBPs 1 and 4 . Hence, in order to separate PBP3 from PBP5 it was necessary to use a technique that exploits the observation that cephalothin is bound to PBP3 at a much lower concentration than results in binding to PBP5 (Chase et al., 1977). Fractions 27, 28 and 29 from the ion-exchange chromatography (see Fig. 2) were pooled and concentrated by ultrafiltration. The concentrated material was incubated with $5 \mu \mathrm{g}$ cephalothin $\mathrm{ml}^{-1}$ for $10 \mathrm{~min}$ at $37^{\circ} \mathrm{C}$ under which conditions cephalothin should bind selectively to PBP3 (Chase et al., 1977). The material was then subjected to covalent affinity chromatography on ampicillin-affinose. PBP5 was adsorbed to the ampicillin-affinose as it did not have cephalothin bound to it and could be subsequently eluted with hydroxylamine. PBP3 was not adsorbed to the column as it was already present as a protein- $\beta$-lactam complex. Cephalothin was removed from PBP3 by treatment of the unadsorbed material with an equal volume of $1 \mathrm{M}$-hydroxylamine in $0.5 \mathrm{M}$-Tris/ $\mathrm{HCl}$ buffer, pH 8.8 containing $0.1 \%(\mathrm{w} / \mathrm{v})$ Genapol $\mathrm{X}-100$ for $30 \mathrm{~min}$ at $37^{\circ} \mathrm{C}$ followed by dialysis against $2 \times 5150 \mathrm{~mm}$-Tris/ $\mathrm{HCl}$ buffer, $\mathrm{pH} 8.0$ at $4{ }^{\circ} \mathrm{C}$. These conditions had been shown previously to result in the removal of cephalothin from PBP3 (Chase et al., 1977). The dialysed material was applied to another column of ampicillin-affinose to which PBP3 and some PBP5 were adsorbed. The PBPs were eluted from ampicillin-affinose by hydroxylamine. Examination of the hydroxylamine eluates by SDS-polyacrylamide gel electrophoresis showed that some PBP3 had been obtained pure in two fractions (Fig. 4, tracks F and G), although four earlier fractions did contain some PBP5. Some fractions contained small amounts of penicillin-binding material that did not correspond to any of the penicillinbinding proteins and these are assumed to have been derived from PBP3 or PBP5 by proteo- 


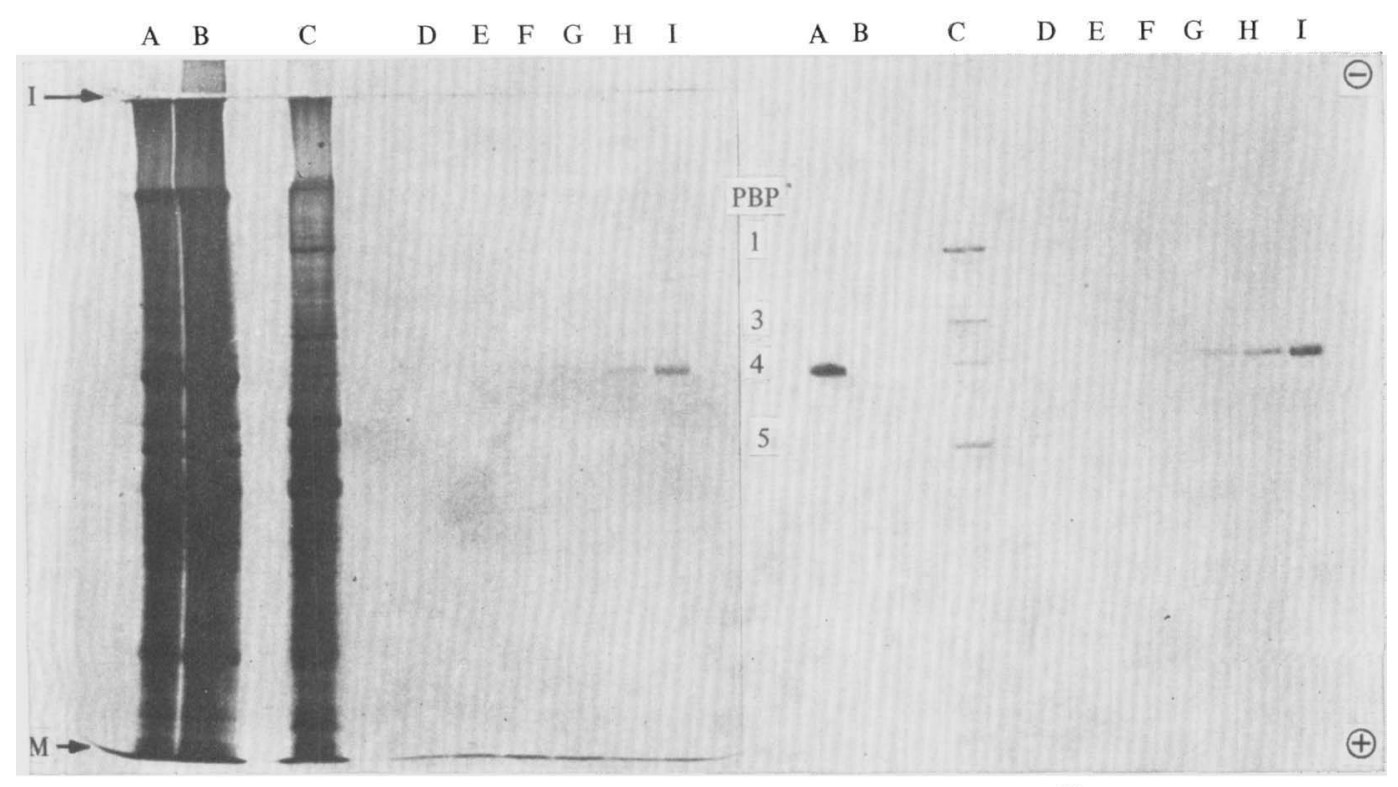

(a)

(b)

Fig. 3. Purification of PBP4 of B. megaterium. Fractions obtained by ion-exchange chromatography containing PBP4 were pooled, concentrated and subjected to covalent affinity chromatography on ampicillin-affinose. Samples of various fractions in the purification procedure were analysed by SDS-polyacrylamide gel electrophoresis. Proteins were revealed by staining with Coomassie brilliant blue $(a)$ and penicillin-binding proteins were detected by fluorography $(b)$. The samples were: (A) pooled, concentrated fractions before affinity chromatography; (B) material not adsorbed to the affinity resin; (C) material solubilized from the membranes; (D to I) material eluted by incubation with hydroxylamine for $0 \mathrm{~min}(\mathrm{D}), 0$ to $1 \mathrm{~min}(\mathrm{E}), 1$ to $10 \mathrm{~min}(\mathrm{~F}), 10$ to $30 \mathrm{~min}(\mathrm{G}), 30$ to $100 \mathrm{~min}$ (H), 100 to $300 \mathrm{~min}(\mathrm{I})$. I indicates the position of the interface between the stacking and the running gels and $\mathrm{M}$ marks the position of the bromophenol blue marker.

lysis. The presence of PBP5 in these fractions was not expected as it indicated that some PBP5 had not been adsorbed to ampicillin-affinose during the first stage of affinity chromatography. Possibly partial binding of cephalothin to PBP5 occurred under the conditions used.

Samples containing pure PBP5 were obtained as described previously (Chase et al., 1977) by covalent affinity chromatography of material treated with low concentrations of cephalothin after solubilization from protoplast membranes. This procedure does not require ionexchange chromatography to achieve separation of the penicillin-binding proteins.

By the above procedures, samples of pure PBPs 1, 3, 4 and 5 were obtained (Fig. 5) which could then be used to ascertain the enzymic activity of these penicillin-binding proteins.

\section{Enzymic activities of the isolated proteins}

Samples of the isolated PBPs 1, 3 and 4 were tested as described in Methods for the enzymic activities specified in Table 1 . No release of D-alanine from UDP-MurNAc-L-AlaD-Glu-( $m s \mathbf{A}_{2}$ pm-D-Ala-D-Ala) or L-Ala-D-Glu- $\left(m s \mathbf{A}_{2}\right.$ pm-D-Ala-D-Ala) was catalysed by purified PBPs 1, 3 or 4 under any of the conditions tested even after prolonged incubation $(5 \mathrm{~h})$. The presence of $\mathrm{Mg}^{2+}(10 \mathrm{~mm})$ and/or an alteration of the $\mathrm{pH}$ of the incubation to $\mathrm{pH} 6$ or 9 did not result in the appearance of any activity. This suggests that PBPs 1, 3 and 4 are not DD-carboxypeptidases capable of catalysing the release of $\mathrm{D}$-alanine from the substrates used. Purified PBP5 showed DD-carboxypeptidase activity towards both substrates 


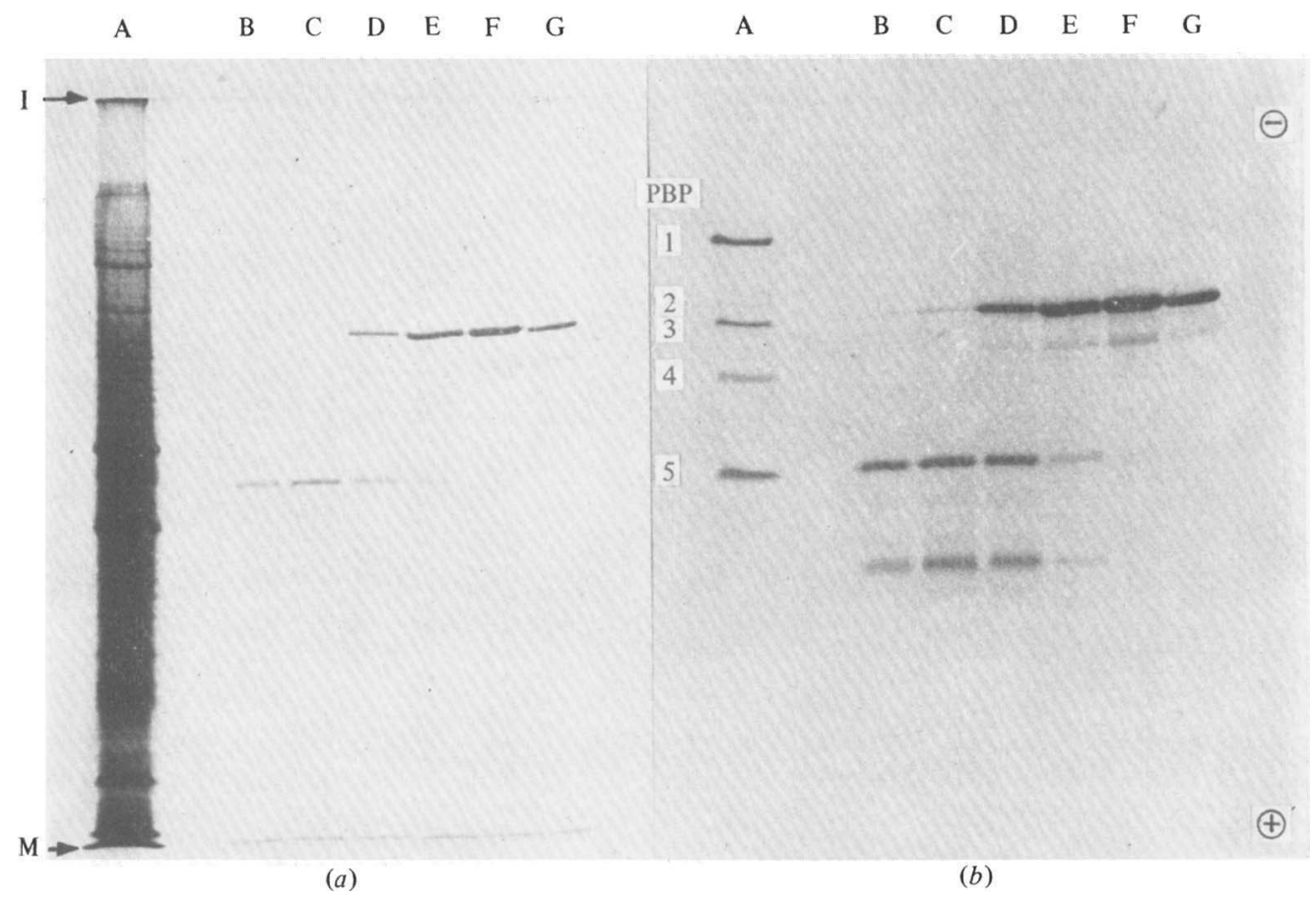

Fig. 4. Purification of PBP3 of $B$. megaterium. Fractions obtained by ion-exchange chromatography containing PBP3 and PBP5 were treated with cephalothin and subjected to affinity chromatography. Material not adsorbed to the column (containing PBP3 and non-penicillin-binding proteins) was treated with neutral hydroxylamine, dialysed and re-subjected to affinity chromatography. Samples of various proteins in the purification procedure were analysed by SDS-polyacrylamide gel electrophoresis. Proteins were revealed by staining with Coomassie brilliant blue $(a)$ and penicillin-binding proteins were detected by fluorography $(b)$. The samples were: (A) cytoplasmic membranes of $B$. megaterium; (B to $\mathrm{G}$ ) material eluted from the second affinity chromatography procedure by incubation with hydroxylamine for $0 \mathrm{~min}(\mathrm{~B}), 0$ to $1 \mathrm{~min}(\mathrm{C}), 1$ to $10 \mathrm{~min}(\mathrm{D}), 10$ to $30 \mathrm{~min}(\mathrm{E})$, 30 to $100 \mathrm{~min}(\mathrm{~F}), 100$ to $300 \mathrm{~min}(\mathrm{G})$. I indicates the position of the interface between the stacking and the running gels and $\mathrm{M}$ marks the position of the bromophenol blue marker.

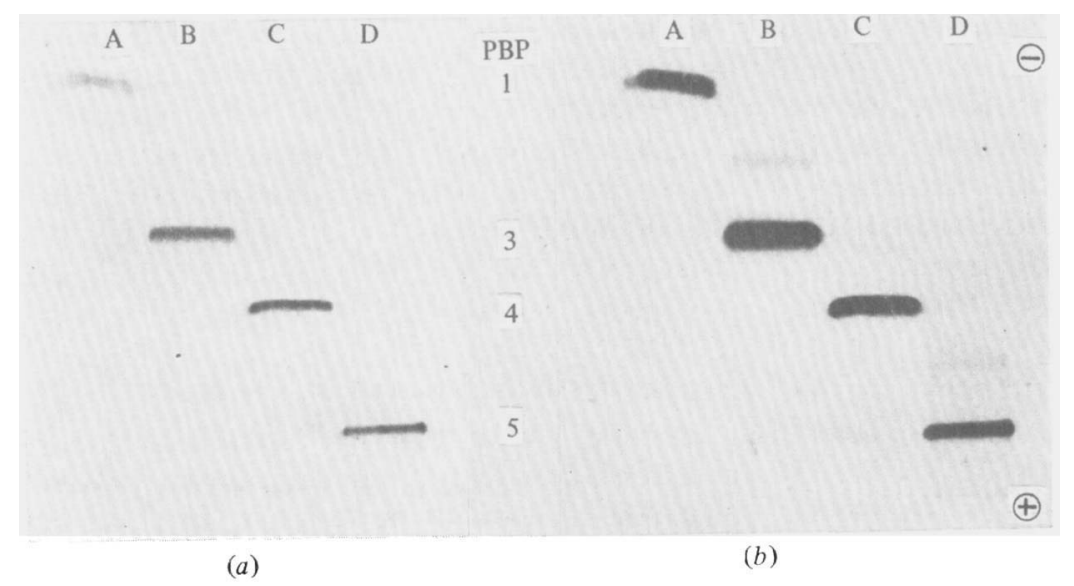

Fig. 5. The purified penicillin-binding proteins of $B$. megaterium. Samples of each of the purified penicillin-binding proteins were analysed by SDS-polyacrylamide gel electrophoresis. Proteins were revealed by staining with Coomassie brilliant blue $(a)$ and penicillin-binding proteins were detected by fluorography (b). The samples were: (A) PBP1; (B) PBP3; (C) PBP4, (D) PBP5. 
under all the above conditions. Samples containing purified PBPs 1, 3 or 4 also showed no enzymic activity towards the substrates L-Ala-D-Glu-([1,7-14 C]ms $\mathrm{A}_{2} \mathrm{pm}$-D-Ala-D-Ala) or MurNAc-L-Ala-D-Glu-([1,7-14C]ms $\mathrm{A}_{2} \mathrm{pm}$-D-Ala-D-Ala) even after incubation for $5 \mathrm{~h}$. In all experiments a single radioactive spot that ran in the same position as the original substrate was observed on the autoradiogram of the electrophoretogram. Samples containing PBP5 catalysed the release of D-alanine from these substrates (i.e. the expected DD-carboxypeptidase activity) as evidenced by the formation of a radioactive compound that migrated in the position expected for L-Ala-D-Glu-([1,7-14 C]ms $\mathrm{A}_{2} \mathrm{pm}$-D-Ala) or the $\mathrm{N}$-acetylmuramoyl derivative. However, there were no spots on the autoradiogram corresponding to the radioactive nonapeptide dimer or the des-Ala octapeptide dimer. Shepherd et al. (1977) observed that the amount of dimer formed by PBP4 of $S$. typhimurium reached a maximum after a certain time and then appeared to be hydrolysed. In order to ensure that a similar situation was not occurring with PBP5 of B. megaterium, a similar time period (involving incubation at $37^{\circ} \mathrm{C}$ for $7,15,30,45$ and $60 \mathrm{~min}$ ) was investigated but no formation of dimer was observed at any time. All experiments were carried out at a variety of $\mathrm{pH}$ values (from $\mathrm{pH} 6$ to 9), in the presence or absence of $\mathrm{MgCl}_{2}(10 \mathrm{~mm})$ and at various ionic strengths (10 to $500 \mathrm{mM}$ ) but no formation of dimers was observed.

The endopeptidase activity of PBPs 1, 3 and 4 was tested by following the appearance of disaccharide peptide monomer GlcNAc-MurNAc-L-Ala-D-Glu- $\left(m s\left[{ }^{14} \mathrm{C}\right] \mathrm{A}_{2} \mathrm{pm}\right.$-D-Ala $)$ arising from hydrolysis of the bisdisaccharide peptide dimer. It has not been possible to observe the formation of monomer under any of the conditions of $\mathrm{Mg}^{2+}$ concentration or $\mathrm{pH}$ described above for transpeptidase activity. This result suggests that none of these penicillin-binding proteins is a peptidoglycan endopeptidase.

\section{DISCUSSION}

Purification of PBPs 1, 3, 4 and 5 of B. megaterium is an important first step in the understanding of the role of penicillin-binding proteins in the cell and their involvement in the lethal action of $\beta$-lactam antibiotics. It should now prove possible to elucidate the biochemical functions of these proteins by finding suitable model systems in which they show biochemical activities. Another approach would be to raise antibodies against the purified proteins and to investigate the effects of such antibodies on the synthesis and morphology of the cell wall. It has not been possible to purify PBP2 of $B$. megaterium as this protein appears to lose its ability to bind benzylpenicillin under the conditions used to solubilize the other penicillin-binding proteins. Hence studies on possible enzymic activities of this protein have not been pursued.

Apart from the purification of PBP4 of Salmonella typhimurium (S. T. Shepherd, personal communication), B. megaterium is the only organism for which the purification of any of the penicillin-binding proteins except the one of lowest molecular weight (the DD-carboxypeptidase) has been reported. Solubilization of penicillin-binding proteins followed by separation by ion-exchange chromatography and isolation by covalent affinity chromatography should be a technique that could be used generally in the purification of penicillinbinding proteins from other organisms. Such a method has been used recently in this laboratory to purify PBP1, PBP4 and PBP5 from E. coli (H. A. Chase, unpublished results).

It has not been possible to show in vitro model transpeptidase activity with any of the penicillin-binding proteins of $B$. megaterium by studying the dimerization of L-Ala-D-Glu( $m s \mathrm{~A}_{2}$ pm-D-Ala-D-Ala). It has also not been possible to show the dimerization of MurNAcL-Ala-D-Glu-( $m s \mathrm{~A}_{2}$ pm-D-Ala-D-Ala) which is of slightly greater chemical similarity to the presumed substrate in the natural peptidoglycan transpeptidation reaction than the pentapeptide substrate. Although there is circumstantial evidence that PBP1 of $B$. megaterium catalyses a penicillin-sensitive peptidoglycan transpeptidation reaction (Reynolds et al., 
1978), it has not been possible to prove this suggestion directly by studying the enzymic activity of the isolated protein. Possibly the natural model transpeptidation reactions are not suitable assays for in vivo peptidoglycan transpeptidases, especially as none of the proteins that catalyse these reactions has been shown to be a peptidoglycan transpeptidase in vivo. Indeed, although PBP4 of $E$. coli can catalyse these natural model transpeptidation reactions (H. A. Chase, unpublished results), there is various genetic evidence that loss of this protein does not affect the growth or morphology of cells and presumably it is not a peptidoglycan transpeptidase in vivo (Iwaya \& Strominger, 1977; Matsuhashi et al., 1977). Hence, the failure of proteins isolated from $B$. megaterium to catalyse the model reactions does not exclude the possibility that these proteins are peptidoglycan transpeptidases. Isolated protoplast membranes of $B$. megaterium are also incapable of catalysing the model reactions (Chase et al., 1977); this observation rules out the criticism that the isolated proteins fail to catalyse the reactions because they have been removed from the membrane and thus have altered properties.

The natural peptidoglycan transpeptidation reaction observed in cell wall plus membrane preparations of B. megaterium (Reynolds, 1971) is coupled to the synthesis of peptidoglycan from nucleotide precursors. These peptidoglycan transpeptidases may require for activity a highly organized spatial configuration between the donor molecule (nascent peptidoglycan) and the acceptor (the cell wall). This spatial configuration may not be reproduced in the model systems and may only be created in the coupled systems in which peptidoglycan is synthesized in situ from precursors. The binding sites on the enzyme for the donor and acceptor may require more complicated substrates than those provided in the model reactions. It is possible that the enzyme does not contain a binding site for the cell wall acceptor but relies on the relative positioning of the cell wall to the membrane to provide a suitably placed amino-acid side-chain to act as an acceptor in the transpeptidation reaction.

The endopeptidase reaction studied is just another manifestation of DD-carboxypeptidase activity as the interpeptide bond that is split [a D-Ala-(D)-meso-diaminopimelyl linkage in an $\alpha$ position relative to a free carboxyl group] fulfils the substrate requirements for a DDcarboxypeptidase. Indeed, Yocum et al. (1974) showed that the isolated DD-carboxypeptidase of $B$. stearothermophilus was capable of catalysing this endopeptidase reaction. However, this reaction is not strictly the reverse of a transpeptidation reaction as the latter requires the cleavage of the dimer by D-alanine rather than by water. Hence, the failure of the penicillin-binding proteins to catalyse the endopeptidation reaction again does not exclude them from being peptidoglycan transpeptidases.

It is unlikely that the isolated penicillin-binding proteins lack enzymic activity as a result of denaturation during the procedures used for solubilization and purification. The purified penicillin-binding proteins still retain the ability to bind $\left[{ }^{14} \mathrm{C}\right]$ benzylpenicillin and the DDcarboxypeptidase (PBP5) can be isolated by these techniques without loss of enzymic or penicillin-binding activities.

The peptidoglycan transpeptidases may be multi-protein complexes consisting of different polypeptide chains which may be held together in the correct quaternary configuration as a result of being bound to the membrane. The procedures used for the purification of the penicillin-binding proteins may split this multi-protein complex into its constituent subunits and it is possible that one subunit contains the binding site for benzylpenicillin (i.e. this is the subunit that has been isolated as it is a penicillin-binding protein) but is not, by itself, catalytically active. If this were the situation, the isolated penicillin-binding proteins would not be expected to possess enzymic activity; they may act as receptors for penicillins but lack enzymic activities themselves.

Some penicillin-binding proteins may be responsible for the triggering of autolytic activity that occurs on treatment of cells with penicillin (Tomasz \& Höltje, 1977). An in vitro assay system to investigate the stimulation by penicillins of the autolytic activity in extracts of Klebsiella pneumoniae and $E$. coli has been reported by Fontana et al. (1977). It may be 
possible to devise a similar kind of system to determine whether any of the penicillin-binding proteins can directly trigger autolytic activity in $B$. megaterium.

I would like to thank Mr C. Fuller for his continued excellent technical assistance. I am indebted to Dr P. E. Reynolds for his advice and encouragement during the course of this work. The work was supported by a grant from the Medical Research Council.

\section{REFERENCES}

BARNETT, H. J. (1973). D-Alanine carboxypeptidases of Bacillus stearothermophilus; solubilisation of particulate enzymes and mechanism of action of penicillin. Biochimica et biophysica acta 304, 332352.

Blumberg, P. M. \& Strominger, J. L. (1972). Isolation by covalent affinity chromatography of the penicillin-binding components from membranes of Bacillus subtilis. Proceedings of the National Academy of Sciences of the United States of America 69, 3751-3755.

Blumberg, P. M. \& Strominger, J. L. (1974). Interaction of penicillin with the bacterial cell: penicillin-binding proteins and penicillin-sensitive enzymes. Bacteriological Reviews 38, 291-335.

Bonner, W. M. \& Laskey, R. A. (1974). A film detection method for tritium-labelled proteins and nucleic acids in polyacrylamide gels. European Journal of Biochemistry 46, 83-88.

BraUN, V. \& REHN, K. (1969). Chemical characterization, spatial distribution and function of a lipoprotein (murein-lipoprotein) of the $E$. coli cell wall. European Journal of Biochemistry 10, 426438.

Braun, V., Bosch, V., Hantke, K. \& Schaller, K. (1974). Structure and biosynthesis of functionally defined areas of the Escherichia coli outer membrane. Annals of the New York Academy of Sciences 235, 66-82.

Chase, H. A., Shepherd, S. T. \& Reynolds, P. E. (1977). Studies on the penicillin-binding components of Bacillus megaterium. FEBS Letters 76, 199-203.

Chase, H. A., Reynolds, P. E. \& Ward, J. B. (1978). Purification and characterization of the penicillinbinding protein that is the lethal target of penicillin in Bacillus megaterium and Bacillus licheniformis. European Journal of Biochemistry 88, 275-285.

Fairbanks, G., Steck, T. L. \& Wallach, D. H. F. (1971). Electrophoretic analysis of the major polypeptides of the human erythrocyte membrane. Biochemistry 10, 2606-2617.

Fontana, R., Satta, G. \& Romanzi, C. A. (1977). Penicillins activate autolysins extracted from both Escherichia coli and Klebsiella pneumoniae envelopes. Antimicrobial Agents and Chemotherapy 12, 745- 747.

Helenius, A. \& Simons, K. (1975). Solubilization of membranes by detergents. Biochimica et biophysica acta 415, 29-79.

IWAya, M. \& Strominger, J. L. (1977). Simultaneous deletion of $\mathrm{D}$-alanine carboxypeptidase IB-C and penicillin-binding component IV in a mutant of Escherichia coli K12. Proceedings of the National Academy of Sciences of the United States of America 74, 2980-2984.
Johnson, K., Duez, C., Frère, J. M. \& Ghuysen, J. M. (1975). Antibiotic inactivation and modification: [53f] $\beta$-lactamases (Actinomycetes species). Methods in Enzymology 43, 687-697.

LaEMmLI, U. K. \& FAVRe, M. (1973). Maturation of the head of bacteriophage T4. I. DNA packaging events. Journal of Molecular Biology 80, 575-599.

LASKEY, R. A. \& Mills, A. D. (1975). Quantitative film detection of ${ }^{3} \mathrm{H}$ and ${ }^{14} \mathrm{C}$ in polyacrylamide gels by fluorography. European Journal of Biochemistry 56, 335-341.

Lawrence, P. J. \& Strominger, J. L. (1970). Biosynthesis of the peptidoglycan of bacterial cell walls. XV. The binding of radioactive penicillin to the particulate enzyme preparation of Bacillus subtilis and its reversal with hydroxylamine or thiols. Journal of Biological Chemistry 245, 36533659.

Martin, H. H., Schilf, W. \& Maskos, C. (1976). Purification of the membrane-bound DD-carboxypeptidase of the unstable spheroplast L-form of Proteus mirabilis by affinity chromatography. European Journal of Biochemistry 71, 585-593.

Matsuhashi, M., TaKagaki, Y., Maruyama, I. N., Tamaki, S., Nishimura, Y., SuzuKi, H., Ogino, U. \& Hirota, Y. (1977). Mutants of Escherichia coli lacking in highly penicillin-sensitive $\mathrm{D}$-alanine carboxypeptidase activity. Proceedings of the National Academy of Sciences of the United States of America 74, 2976-2979.

Nguyen-Distèche, M., Ghuysen, J. M., Pollock, J. J., Reynolds, P. E., Perkins, H. R., Coyette, J. \& Salton, M. R. J. (1974). Enzymes involved in wall peptide cross-linking in Escherichia coli K12, strain 44. European Journal of Biochemistry 41, 447-455.

Penefsky, H. S. \& Tzagoloff, A. (1971). Specific organelles. [19] Extraction of water soluble enzymes and proteins from membranes. Methods in Enzymology 22, 204-219.

Pollock, J. J., Nguyen-Distèche, M., Ghuysen, J. M., Coyette, J., Linder, R., SAlton, M. R. J., Kim, K. S., Perkins, H. R. \& Reynolds, P. E. (1974). Fractionation of the DD-carboxypeptidasetranspeptidase activities solubilized from membranes of Escherichia coli K12, strain 44. European Journal of Biochemistry 41, 439-446.

Reynolds, P. E. (1971). Peptidoglycan synthesis in bacilli. I. Effect of temperature on the in vitro system from Bacillus megaterium and Bacillus stearothermophilus. Biochimica et biophysica acta 237, 239-254.

Reynolds, P. E., Shepherd, S. T. \& Chase, H. A. (1978). Identification of the binding protein that may be the target of penicillin action in Bacillus megaterium. Nature, London 271, 568-570. 
Shepherd, S. T., Chase, H. A. \& Reynolds, P. E. (1977). The separation and properties of two penicillin-binding proteins from Salmonella typhimurium. European Journal of Biochemistry 78, $521-532$.

SpratT, B. G. (1975). Distinct penicillin-binding proteins involved in the division, elongation and shape of Escherichia coli K12. Proceedings of the National Academy of Sciences of the United States of America 72, 2999-3003.

Sprat, B. G. (1977). Penicillin-binding proteins of Escherichia coli: general properties and characterization of mutants. In Microbiology-1977, pp. 182-190. Edited by D. Schlessinger. Washington, D.C.: American Society for Microbiology.

Spratt, B. G. \& StromingER, J. L. (1976). Identification of the major penicillin-binding proteins of Escherichia coli as D-alanine carboxypeptidase IA. Journal of Bacteriology 127, 660-663.

Tamaki, S., NaKajima, S. \& Matsuhashi, M. (1977). Thermosensitive mutation in Escherichia coli simultaneously causing defects in penicillinbinding protein-1Bs and in enzyme activity for peptidoglycan synthesis in vitro. Proceedings of the National Academy of Sciences of the United States of America 74, 5472-5476.

Tomasz, A. \& HöltJe, J. V. (1977). Murein hydrolases and the lytic and killing action of penicillin. In Microbiology 1977, pp. 209-215. Edited by D. Schlessinger. Washington, D.C.: American Society for Microbiology.

Van Heijenoort, J., Elbaz, L., Dezélée, Ph., Petit, J. I., Bricas, E. \& Ghuysen, J. M. (1969). Structure of the meso-diaminopimelic acid containing peptidoglycans in Escherichia coli $\mathbf{B}$ and Bacillus megaterium KM. Biochemistry 8, 207-213. Yocum, R. R., Blumberg, P. M. \& Strominger, J. L. (1974). Purification and characterisation of the thermophilic D-alanine carboxypeptidase from membranes of Bacillus stearothermophilus. Journal of Biological Chemistry 249, 4863-4871. 